\title{
Ways of Detection of Creative Accounting in a Global Economy
}

\author{
Lenka Hrosova ${ }^{1, *}$ \\ ${ }^{1}$ University of Zilina, Faculty of Operation and Economics of Transport and Communications, \\ Univerzitna 1, 01026 Zilina, Slovakia
}

\begin{abstract}
Research background: Any entity operating in a global economic environment is required to conduct an accounting agenda in such a way that its financial statements are prepared in a clear, comprehensible manner and adhere to the accounting principle of fair and true presentation of accounting facts as it serves as a source of information for internal and other external entities using this information in its economic decision-making. It is the principle of accurate and true presentation of accounting information that plays an important role in the field of creative accounting, in which the accounting data is adjusted or manipulated to the desired form.

Purpose of the article: The main goal of this paper is to point out the issue of creative accounting and the possibility of its detection using selected models.

Methods: The methodological part is focused on the application of the Beneish model and CFEBT model assuming the use of creative techniques in the period 2016-2020.

Findings \& Value added: The summary of the results of the analysis thus points to the use of creative accounting in a given accounting entity according to the Beneish model and CFEBT model, but this accounting entity, despite its use, did not violate the principle of a true and fair representation of the accounting reality.
\end{abstract}

Keywords: creative accounting; detection of creative accounting; Beneish model; CFEBT model; financial statement

JEL Classification: $M 41$

${ }^{*}$ Corresponding author: lenka.strakova@,fpedas.uniza.sk 


\section{Introduction}

Each entity in the global business environment should conduct an accounting agenda (Ayu et al., 2020) by the accounting principles (Savova, 2021) and principles arising from the laws of that country. It is the principle of accurate and true presentation of accounting information that plays an important role in the field of creative accounting (Blazek et al., 2020), in which the accounting data is adjusted or manipulated to the desired form (Grofcikova, 2020). Deteriorating economic conditions and a negative outlook increases the pressure on financial management and the need to show high financial performance (Durana et al. 2021). The enterprises with a financial health-oriented strategy can enjoy a competitive advantage (Kliestik et al. 2020). The profit is the effect of the enterprise's business activity and, at the same time, is often the measure of whether the company is successful or not (Siekelova and Podhorska, 2020). The rising cases of high-profile corporate failures in recent years have been a source of concern to all stakeholders. Thus, the public has become more critical of the effectiveness of corporate governance mechanisms in reducing creative accounting practices (Olojede et al., 2021). This is also the reason why more and more scientists are interested in the probability of manipulation of earnings (Kliestik et al., 2021; Siekelova et al., 2021) and thus achieving the required numbers in the global economy (Khuong et al., 2020). Earnings Management), which is also presented by creativity in accounting. There is no established definition of the concept of creative accounting in the professional literature, but several scientists dealing with this issue define the concept of creative accounting as follows. Naser (1994) explains creative accounting as a process of modifying economic results from a true picture to the desired results. This can be achieved by improper use or even abuse of existing rules or omission of other rules. Naser sees the accounting system, especially in Anglo-Saxon countries, as an extremely receptive environment for creative accounting. Griffiths (1995) points out that companies present results that do not give a true and fair view of their transactions, but rather adjust them to the desired objectives. The economic results that enterprises report are based on appropriate, adjusted, or changed data. These practices used in reporting business operations or performance are considered creative accounting. Mulford and Comiskey (2002) define creative accounting as "the steps used to play with financial statements, including the aggressive selection and application of accounting principles, either within or beyond generally accepted accounting principles, and fraudulent accounting." to the definition of creative accounting, they explain fraudulent accounting as the deliberate misrepresentation or omission of certain values and notes in financial statements made for misleading users of those financial statements and perceived as fraudulently administrative, civil or criminal. Schipper (1989) considers creative accounting to be a purposeful intervention in the company's financial reporting process, which can be compared to a secure solution for automating the company's financial processes and financial reporting, known in the literature as disclosure management. Drábková (2017) points to the existing problem of defining the boundaries of accounting creativity or the so-called gray economy and identifying accounting fraud, also known as the black economy, which we already call economic crime. In the literature, the definition of creative accounting varies considerably. However, it is possible to compare the prevailing views of authors dealing with the issue, which show that if the determination of accounting procedures does not violate the Accounting Act or other related accounting regulations, it is creative accounting and not accounting fraud. Creativity in accounting, therefore, represents manipulation of financial statements, which consists in adjusting the true and true image of accounting, which changes the accounting reality, but only to the extent that it is not illegal. Within the issue of creative accounting, it is therefore important to understand the meaning of this term in the territory of individual countries of the world, depending on their legislative and regulatory framework. 
The main goal of this paper is to present the issue of creative accounting and the possibilities of its detection. In the global economy, several detection methods are used to detect creative accounting in companies in the world. Beneish (1999) created a probabilistic model consisting of eight variables that need to be calculated to obtain the final value of Benish's M-SCORE. Variables include days sales in the receivable index (DSRI), gross margin index (GMI), asset quality index (AQI), sales growth index (SGI), depreciation index (DEPI), sales and general administrative expenses index (SGAI), leverage index (LVGI), total accruals to total assets (TATA). The resulting value of the Beneish M-score is then compared with the value -1.78 , while if the Beneish $\mathrm{M}$-score is higher than the value -1.78 , it indicates the manipulation of financial statements and thus the use of creative techniques in the company. Piotroski (2014) has created a model that works with profitability and liquidity indicators, which are usually the subject of manipulation of accounting data if the company does not report the required results in its business activities. The model consists of nine criteria, with each criterion assigned a point one or a zero point. The overall evaluation of individual criteria makes it possible to assess the financial situation of companies in the global economic environment. Another of the detection methods of creative accounting is the Q-DMFCA model created based on four balances, namely material, energy, financial and legal. The company's material balance examines and records the company's inventories in kind (Haskins et al., 2020) the company's energy balance examines and records energy consumption and resources spent, the company's financial balance examines the financial situation and keeps financial records of production and the company's legal balance checks whether the company complies with the necessary legal standards. One of the detection methods of creative accounting is also the model of twelve signals. The model contains 12 signals that can measure the value of revenues and future growth of companies in the global business environment. Each of the signals provides a set of information that users can use in the implementation of creative accounting, and each of the signals must meet certain criteria, based on which each of the signals is evaluated as a positive or negative signal. The more positive signals the model contains, the better the quality of future revenues and business growth in the global business environment. However, the model is also characterized by limitations in the complexity of obtaining information, as some of the signals are not available to ordinary users or can not be applied, which results in a reduction in its detection ability in the field of creative accounting.

\section{Methods}

The methodological part is focused on the application of two detection methods, namely the Beneish model and the CFEBT model assuming the use of creative techniques in the period 2016-2020. The Beneish model is a mathematical model composed of eight variables that can be used to detect the manipulation of accounting data. To determine the Beneish M-score, it is necessary to determine the values of individual variables contained in the Beneish model itself and then calculate the Beneish M-score and determine whether the company uses creative accounting techniques to manipulate its profits or not. The basis for obtaining the accounting data needed to determine the resulting values of individual variables contained in the Beneish model is the financial statements of the company. The formula for calculating the Beneish M-score is as follows.

$$
\begin{gathered}
M-\text { score }=-4,84+0,92 \times D S R I+0,528 \times G M I+0,404 \times A Q I+ \\
0,892 \times S G I+0,115 \times D E P I-0,172 \times S G A I+4,679 \times T A T A-0,327 \times \\
L V G I
\end{gathered}
$$


If the resulting value of the Beneish $\mathrm{M}$-score reaches a value higher than -2.22 , it means that the entity manipulates its profit in the given accounting period or is motivated to do so. The methodology of the CFEBT model consists of two phases. The first phase is focused on determining the CFEBT score at a level of significance ranging from 5 to $10 \%$, where the following equation is used to calculate the CFEBT score, taking into account the relationship between $\mathrm{CF}$ and EBT.

$$
C F E B T=\frac{\sum_{t=1}^{5} C F_{t}-\sum_{t=1}^{5} E B T_{t}}{\sum_{t=1}^{5} E B T_{t}} \cdot 100
$$

If the CFEBT value of the model is higher than the significance value, it is necessary to subsequently analyze the fluctuations between CF and EBT. These fluctuations are assessed at the materiality level for each item of account, resulting in CF and EBT variations in the form of additions or disposals. It is an analysis of individual areas, which is used to determine whether the analyzed entity violated the principle of a true and fair presentation of accounting facts in the period under review.

\section{Results and Discussion}

The resulting values of individual variables can be evaluated based on Beneish indicators. Based on the resulting values of variables and values of risk items, we see that the variable AQI reached a higher value in the observed year 2017 compared to the risk item as well as in 2019 and 2020, which results in the incorrect capitalization of expenditures. The GMI variable reached a risk value in 2020 , which arose as a result of economic problems. The SGI variable was assessed as risky in 2018, resulting in fictitious returns. The DEPI variable reached a risk value in four consecutive periods, which resulted in the manipulation of profits through an artificial extension of the useful life of the company's long-term assets and overvaluation of income. The SGAI variable acquired a risk value in two years, namely 2016 and 2019, which also points to profit manipulation. The LVGI variable was issued as risky in the three years 2016, 2019, and 2020, which creates the assumption of using one of the techniques of creative accounting, namely earnings management. The variables DSRI and TATA were not evaluated as risky in any of the observed periods.

Table 1. Variables of Beneish Model and Risk Items

\begin{tabular}{|c|c|c|c|c|c|c|}
\hline Variables & Risk Items & 2016 & 2017 & 2018 & 2019 & 2020 \\
\hline DSRI & $\geq 1.465$ & 1.011 & 1.211 & 1.101 & 1.312 & 0.912 \\
\hline GMI & $\geq 1.193$ & -0.152 & -13.816 & 0.983 & 1.016 & 1.989 \\
\hline AQI & $\geq 1.254$ & 0.008 & 4.296 & 1.125 & 3.475 & 2.336 \\
\hline SGI & $\geq 1.607$ & 1.039 & 0.887 & 1.951 & 0.912 & 0.936 \\
\hline DEPI & $\geq 1.077$ & 1.021 & 1.178 & 1.957 & 1.938 & 1.447 \\
\hline SGAI & $\geq 1.041$ & 1.934 & 0.978 & 1.006 & 1.981 & 0.905 \\
\hline LVGI & $\geq 1.111$ & 1.853 & 0.956 & 0.936 & 1.919 & 1.121 \\
\hline TATA & $\geq 0.031$ & -0.092 & -0.095 & -0.094 & -0.057 & -0.156 \\
\hline
\end{tabular}

Source: Made by author

Based on the results of the Beneish M-score, we see that in three of the analyzed years, the value of the Beneish M-score was lower than -2.22 , which means that no manipulation of the profit was recorded in the given years. In the two monitored periods, the value of the Beneish M-score acquired a value greater than -2.22 , which indicates a higher risk of manipulation of accounting data, ie manipulation of profit. 
Table 2. Beneish M-score

\begin{tabular}{|c|c|c|}
\hline Year & Beneish M-score & Risk Assessment \\
\hline 2016 & -4.31 & $<-2.22$ \\
\hline 2017 & -9.28 & $<-2.22$ \\
\hline 2018 & -1.81 & $>-2.22$ \\
\hline 2019 & -1.89 & $>-2.22$ \\
\hline 2020 & -2.26 & $<-2.22$ \\
\hline
\end{tabular}

Source: Made by author

Table 3. CFEBT Model

\begin{tabular}{|c|c|c|}
\hline Year & EBT & $\mathrm{CF}$ \\
\hline 2016 & 38,257 & 10,805 \\
\hline 2017 & 32,155 & 17,497 \\
\hline 2018 & 27,954 & 26,651 \\
\hline 2019 & 26,982 & 17,839 \\
\hline 2020 & 22,732 & 10,253 \\
\hline SUM & 144,080 & 83,045 \\
\hline CFEBT & \multicolumn{2}{|c|}{$42 \%$} \\
\hline Modified CFEBT & \multicolumn{2}{|c|}{$6 \%$} \\
\hline
\end{tabular}

Source: Made by author

In the observed period 2016-2020, the EBT indicator had a declining trend. In the element of 2016, it reached the highest value, then from year to year, its value decreased. The CF value in the observed period had a changing character. From 2016-2018, its values grew, but from 2018 until 2020, when CF was the highest, its development began to decline. In all analyzing years, both indicators reached a positive value. Based on the individual values of both indicators, the results of the CFEBT model measuring the risk of manipulation with accounting data for the observed period 2016-2020 point to an increased risk of manipulation. In the monitored period, the value of the CFEBT model reached the level of $42 \%$, which represents a higher percentage of risk than the considered level of significance with a level of $5-10 \%$. After the value of the CFEBT model has been higher compared to the level of significance, it is also necessary to take into account fluctuations between CF and EBT. Their relationship is evaluated based on the materiality of individual accounting items affecting the development of both indicators in the period under review through their decreases or additions to assess whether the entity violated the accounting principle of true and fair view of the accounting fact or not. These are accounting items such as depreciation, changes in provisions and reserves, changes in receivables and payables, changes in inventories, or changes in loans and borrowings. The value of the modified CFEBT model reached a score of $6 \%$. This percentage is in the range of a materiality level of $5 \%$ to $10 \%$, which means that while an entity uses creative accounting techniques to modify accounting data, it is only to the extent that it is not illegal, that is, it does not violate the principle of fairness and true view of accounting.

\section{Conclusion}

Any entity operating in a global economic environment is required to conduct an accounting agenda in such a way that its financial statements are prepared in a clear, comprehensible 
manner and adhere to the accounting principle of fair and true presentation of accounting facts as it serves as a source of information for internal and other external entities using this information in its economic decision-making. It is the principle of accurate and true presentation of accounting information that plays an important role in the field of creative accounting, in which the accounting data is adjusted or manipulated to the desired form. The main goal of this paper was to point out the issue of creative accounting and the possibility of its detection using the Beneish model and CFEBT model. According to the results of the Beneish M-score analyzed accounting entity used technics of creative accounting in the two monitored periods in which Beneish M-score was higher than -2.22. The CFEBT model was used on the equal accounting entity. Based on the individual values of both indicators, the results of the CFEBT model measuring the risk of manipulation with accounting data for the observed period 2016-2020 point to an increased risk of manipulation. In the monitored period, the value of the CFEBT model reached the level of $42 \%$, which represents a higher percentage of risk than the considered level of significance with a level of 5-10\%. Based on it there was analyzed account fluctuation between CF and EBT according to the Modified CFEBT model. The value of the modified CFEBT model reached a score of $6 \%$. This percentage was in the range of a materiality level of $5 \%$ to $10 \%$, which meant that while an entity used creative accounting techniques to modify accounting data, it was only to the extent that it was not illegal, that was, it did not violate the principle of fairness and true view of accounting.

\section{Acknowledgements}

This paper was prepared with the support of APVV-17-0546 Variant Comprehensive Model of Earnings Management in Conditions of The Slovak Republic as an Essential Instrument of Market Uncertainty Reduction which authors gratefully acknowledge.

\section{References}

1. Ayu, M., Gamayuni, R. R., \& Urbanski, M. (2020). The impact of environmental and social costs disclosure on financial performance mediating by earning management. Polish Journal of Management Studies, 21(1), 74-86.

2. Beneish, M. D., Lee, C. M. C. \& Nichols, D. C. (2013). Earnings Manipulation and Expected Returns. Financial Analysts Journal, 69(2), 57-82.

3. Blazek, R., Durana, P. \& Valaskova, K. (2020). Creative Accounting as an Apparatus for Reporting Profits in Agribusiness. Journal of Risk and Financial Management, 13(11), Article 261.

4. Drabkova, Z. (2017). CFEBT risk triangle of accounting errors and frauds - analytical tool of fraud risk management and reduction of information asymmetry between creators and users of accounting reports. 5th International Scientific Conference on IFRS - Global Rules and Local Use, 286-299.

5. Durana, P., Michalkova, L., Privara, A., Marousek, J., \& Tumpach, M. (2021). Does the life cycle affect earnings management and bankruptcy? Oeconomia Copernicana, 12(2), 425-461.

6. Griffiths, I. (1995). New Creative Accounting: How to Make Your Profits What You Want Them to Be. Palgrave MacMillan.

7. Grofcikova, J. (2020). Impact of selected determinants of corporate governance on financial performance of companies. Ekonomicko-manazerske spektrum, 14(2), 12-23. 
8. Haskins, P., Luțan, P. A. G., \& Tanase, A. (2020). Sustainable Value Creation Networks, Digitized Mass Production, and Networked Information-driven Technologies in Industry 4.0-based Manufacturing Systems. Economics, Management, and Financial Markets 15(2), 37-43.

9. Khuong, N. V., Liem, N. T., \& Minh, M. T. H. (2020). Earnings management and cash holdings: Evidence from energy firms in Vietnam. Journal of International Studies, 13(1), 247-261.

10. Kliestik, T., Belas, J., Valaskova, K., Nica, E., \& Durana, P. (2021). Earnings management in V4 countries: the evidence of earnings smoothing and inflating. Economic Research-Ekonomska Istrazivanja, 34(1), 1452-1470.

11. Kliestik, T., Valaskova, K., Lazaroiu, G., Kovacova, M., \& Vrbka, J. (2020). Remaining Financially Healthy and Competitive: The Role of Financial Predictors. Journal of Competitiveness, 12(1), 74-92.

12. Mulford, CH. \& Comiskey, E. (2002). The Financial Numbers Game: Detecting Creative Accounting Practices. LLC.

13. Naser, K. H. M. (1993). Creative Financial Accounting: It's nature and use. Prentice Hall.

14. Olojede, P. \& Erin, O. (2021). Corporate governance mechanisms and creative accounting practices: the role of accounting regulation. International Journal of Disclosure and Governance, 18(3), 207-222.

15. Piotroski, J. D. (2014). Financial reporting Practices of China's Listed Firms. Journal of Applied Corporate Finance, 26(3), 53-60.

16. Savova, K. (2021). Variable application of accounting standards - current aspects. Ekonomicko-manazerske spektrum, 15(1), 111-122.

17. Schipper, K. (1989). Earnings management. Accounting Horizons, 3(4), 91-102.

18. Siekelova, A., Belas, J., Podhorska, I., Durana, P. (2021). Accrual-Based Earnings Management: A Case Study in V4 Focusing on Mining And Quarrying Sector. Acta Montanastica, Slovaca, 26(1), 70-83.

19. Siekelova, A., \& Podhorska, I. (2020). Earnings indicators under the condition of globalization. 19th International Scientific Conference Globalization and Its SocioEconomic Consequences - Sustainability in the Global-Knowledge Economy, 74. 